\title{
UMA ANÁLISE DO MERCADO DO TRANSPORTE DUTOVIÁRIO DE PETRÓLEO SEUS DERIVADOS E GÁS NATURAL NO BRASIL
}

\author{
Alencar Chaves Braga \\ Universidade Federal de São Paulo \\ alencarcbraga@gmail.com \\ Ana Carolina Corrêa da Costa Leister \\ Universidade Federal de São Paulo \\ carolina.Leister@unifesp.br
}

\begin{abstract}
RESUMO
O objetivo desta pesquisa foi identificar os principais entraves jurídicos e tipicamente econômicos para o desenvolvimento do modal dutoviário, destinados ao transporte de petróleo, seus derivados e gás natural, no Brasil. Com base na literatura sobre dutos, buscou-se o arcabouço teórico de como funciona este modal na logística do petróleo, seus derivados e gás natural, assim como seus aspectos econômicos visando conhecer a estrutura deste mercado. Depois de caracterizado oleodutos e gasodutos, foram mapeadas as principais leis e resoluções da ANP que regulam o setor e identificado as fontes de barreiras deste mercado. Como resultado da análise, foram identificadas sete barreiras de entrada das organizações no mercado dutoviário: (1) Falta de instrumentos regulatórios de garantia por demanda em novos oleodutos; (2) A Lei 9.478 não prevê instrumentos financeiros de incentivos para empreendimentos de novos oleodutos; (3) Processo de obtenção do licenciamento ambiental do empreendimento; (4) Capacidade técnica; (5) Direitos de acesso pode limitar o exercício legal do direito de uso pelo operador de dutos; (6) Falta de critério no reajuste tarifário dos serviços de transporte dutoviário; (7) Complexidade no plano de Manutenção.
\end{abstract}

Palavras-chave: Modal dutoviário. Barreiras de entrada. Mercado. Oleodutos. Gasodutos.

\section{A MARKET ANALYSIS OF PIPELINE TRANSPORT OF OIL, ITS DERIVATIVES AND NATURAL GAS IN BRAZIL}

\begin{abstract}
The purpose of this research was to identify the main legal and typically economic obstacles to the development of the pipeline modal, destined to transport oil, refined petroleum products and natural gas, in Brazil. Based on the literature on pipelines, was sought the theoretical framework of how this model works in the logistics of oil, refined petroleum products and natural gas, as well as its economic aspects and aiming to know the structure of this market. After oil and gas pipelines were characterized, the main laws and ANP resolutions that regulate the sector were mapped and identified the sources of barriers in this market. As a result of the analysis, seven entry barriers of organizations in the pipeline market were identified: (1) Lack of regulatory instruments that guarantee on demand for new oil pipelines; (2) Law 9.478 does not provide financial incentive instruments for new oil pipeline projects; (3) Process of obtaining the environmental license of the development; (4) Technical capacity; (5) Access rights may limit the legal exercise of the right of use by the pipeline operator; (6) Lack of criterion in the tariff readjustment of the pipeline transportation services; (7) Complexity in the Maintenance Plan.
\end{abstract}

Key words: Pipeline modal. Entry barriers. Market. Oil pipelines. Gas pipelines. 


\section{INTRODUÇÃO}

Ao longo do tempo, o petróleo foi se impondo como fonte de energia. Hoje, com o advento da petroquímica, além da grande utilização dos seus derivados, centenas de novos compostos são produzidos, muitos deles diariamente utilizados, como plásticos, borrachas sintéticas, tintas, corantes, adesivos, solventes, detergentes, explosivos, produtos farmacêuticos, cosméticos, etc. Com isso, o petróleo, além de produzir combustível, passou a ser imprescindível às facilidades e comodidades da vida moderna (THOMAS, 2001). A necessidade de transportar produtos combustíveis líquidos ou gasosos entre dois pontos gera a oportunidade da implantação de um projeto de dutos. Para determinados volumes e distâncias, o transporte de produtos combustíveis por dutos, quando comparado com outros modais de transporte como rodoviário e ferroviário, geralmente se apresenta como alternativa econômica mais vantajosa, confiável e segura (RENNÓ; LEMGRUBER, 2009).

Em muitos países, as redes de dutos são de propriedade e operadas por entidades governamentais. Em outros casos, embora operadas por empresas privadas, há pouca concorrência de preços ou participação de mercado e o governo mantém o controle efetivo (KENNEDY, 1993).

O Brasil possui uma malha de dutos em operação, destinados ao transporte de gás natural, petróleo e seus derivados, com extensão de 14.256 quilômetros (AGÊNCIA NACIONAL DO PETRÓLEO, 2016). Apesar da importância do modal dutoviário, a malha de dutos do Brasil ainda é pequena em comparação a outros países. Em 2013 havia em operação no Estados Unidos 98.026 quilômetros de dutos de petróleo e 102.244 quilômetros de derivados de petróleo (ASSOCIATION OF OIL PIPE LINES, 2016). A malha de gasodutos no Estados Unidos possui aproximadamente 482.803 quilômetros de dutos destinados ao transporte de gás natural (PIPELINE 101, 2016).

A malha de dutos é fundamental para o desenvolvimento econômico do país, especialmente por se direcionar para o setor de petróleo e gás natural. Entre 2000 e 2014, a participação do segmento de petróleo e gás natural no Produto Interno Bruto (PIB) do Brasil aumentou de $3 \%$ para 13\% (PORTAL BRASIL, 2014). O aumento da produção de petróleo do Pré-Sal, demandará investimentos na expansão da infraestrutura de dutos. Os serviços de apoio logístico, que serão necessários, devem atender a cadeia produtiva do petróleo.

$\mathrm{Na}$ estrutura de mercado do modal dutoviário, a entrada de agentes econômicos ou a sua saída são determinadas por peculiaridades desse mercado. Faz parte da atuação do Estado impor restrições ou incentivos aos agentes do mercado. O Estado, agente regulador, deve intervir como um elemento facilitador, removendo total ou parcialmente as barreiras de entrada no mercado. Nesse sentido, o governo precisa criar mecanismos e incentivos no intuito de fomentar o setor dutoviário, facilitando a entrada de agentes nesse mercado, atraindo investidores de modo que esses investimentos possam ser feitos no curto prazo. Além disso, deve garantir o abastecimento e o fornecimento de petróleo, seus derivados e gás natural aos consumidores.

Ademais, empresas operadoras de dutos estabelecidas devem possuir conhecimento preciso das fontes especificas de cada barreira para que possa explorá-las efetivamente. Para Porter (1989), uma empresa deve determinar que concorrentes em potencial são mais perigosos, e as formas como poderiam optar por comportar-se. Só então as táticas de defesa apropriadas podem ser reunidas. Uma etapa importante na detenção de concorrentes é compreender inteiramente as barreiras existentes. Uma empresa deve ter uma nítida compreensão das barreiras de entrada que ela possui atualmente, de suas fontes específicas e do modo como poderiam alterar-se. A dimensão das barreiras existentes modela a extensão da ameaça à posição de uma empresa. Se as barreiras estiverem caindo, por exemplo, elas devem ser reconstruídas ou substituídas para que a empresa preserve sua rentabilidade.

Por essa razão, o presente estudo tem como principal objetivo identificar os principais entraves jurídicos e tipicamente econômicos para o desenvolvimento do mercado do modal dutoviário, destinados ao transporte de petróleo, seus derivados e gás natural, no Brasil. Ao ampliar o conhecimento sobre o mercado do modal dutoviário no Brasil, pretendeu-se fomentar o debate e a reflexão sobre o tema, bem como fornecer ações para o desenvolvimento deste mercado. 


\section{PROCEDIMENTOS METODOLÓGICOS}

O trabalho foi desenvolvido em três etapas. Na primeira etapa da pesquisa consistiu identifcar como funciona o modal dutoviário na logística do petróleo, seus derivados e gás natural, compreender a finalidade dos oleodutos e gasodutos, incluindo suas diferenças, assim como dos aspectos econômicos deste modal. Como o objetivo de pesquisa é estudar os entraves do desenvolvimento do mercado dutoviário, faz-se necessário então, analisar a relação entre o Estado nacional com os recursos naturais, econômicos e o contexto no qual o modal dutoviario está inserido. Neste sentido, analisaremos circunstâncias em que o transporte dutoviário se tornou tema geopolítico, incluindo a evolução deste modal no Brasil. Buscou-se na literatura conhecer estrutura de mercado, como ocorre a classificação do ambiente competitivo existente. Além disso, procurou-se também conhecer as principais fontes de barreiras de entrada indicado por Porter (2004).

$\mathrm{Na}$ segunda etapa, com base na caracterização de oleodutos e gasodutos, foram mapeadas as principais leis e resoluções da ANP que regulam o setor. Por fim, na terceira etapa realizou-se a análise de leis e resoluções da ANP. O levantamento preliminar das fontes de barreiras de entrada no mercado dutoviário foi confrontado com leis e resoluções da ANP, identificando fontes de barreiras.

Portanto, baseia-se este trabalho em pesquisa documental de leis e resoluções existentes da Agencia Nacional do Petróleo (ANP) que regulamenta o setor de transporte dutoviário de petróleo, seus derivados e gás natural, os quais estão indicados na Tabela 1 (Leis e Resoluções da ANP). Com base nesse levantamento, foi possível identificar as principais fontes de barreiras de entrada neste mercado. Destaca-se que a pesquisa terá início com análise da Lei $N^{\circ} 9.478$, que dispõe sobre a política energética nacional e a lei 11.909, que dispões sobre as atividades relativas ao transporte de gás natural (BRASIL, 2009).

\section{OLEODUTOS E GASODUTOS}

Biolchini (2001) analisa que no abastecimento de petróleo e seus derivados, o sistema de transporte se estruturou em função das características formadas pelas posições relativas das regiões de produção de óleo, das refinarias e dos polos de suprimento dos mercados consumidores de derivados. A grande importância do transporte no comércio de petróleo e seus derivados é devido principalmente em função da grande dispersão geográfica entre as zonas de produção e os centros consumidores.

Assim, o petróleo necessita ser transportado em quantidades muito grandes por longas distâncias e somente uma combinação da utilização do modal marítimo, através de navios petroleiros, com os oleodutos é que se torna possível o transporte de óleo cru em grandes quantidades, de forma otimizada. Silva (2003) expõe que quando uma carga não pode ser transferida diretamente de um modal a outro nas condições em que chega ao terminal, é preciso que o terminal ou ponto de transferência esteja equipado adequadamente para efetivar tal operação. Cada tipo de carga tem suas particularidades com relação a necessidades de transferência entre modais.

Oleodutos transportam também derivados de petróleo de refinarias aos terminais, incluindo terminais de distribuição, destinados ao mercado consumidor. Dentre esses produtos estão os vários tipos de gasolina, diesel, nafta e querosene de aviação.

Kandiyoti (2012) explica que em geral, a engenharia de produção e transporte de gás natural é mais complexa e cara do que a infraestrutura para o transporte de óleo cru. O desenvolvimento de campos de gás natural requer maiores prazos de entrega do que corresponde projetos de óleo cru. Por outro lado, assegurar o investimento em gasodutos exige segurança em contratos de longo prazo, muitas vezes mais de dez anos. Os consumidores, por sua vez, exigem garantias de fornecimento de longo prazo. O transporte de gás natural difere do transporte de petróleo e seus derivados em vários aspectos importantes. Em primeiro lugar, vagões de trens e caminhões não são viáveis para operações de grande escala e são raramente utilizados. Além disso, em caso de ruptura, o gás natural não apenas vaza ou incendeia, como óleo cru faz, mas pode explodir. Linhas de gás são, portanto, mais caras de construir e a segurança é sempre um problema mais crítico.

Pereira, Silva e Venezia (2014) completam que o transporte por dutos é a solução tecnicamente mais adequada para escoar a produção de gás natural até os centros consumidores. Para realizar a movimentação do gás natural através dos dutos de transporte, é necessário injetá-lo em alta pressão. À medida que o gás se movimenta, a pressão diminui, tornando necessária a instalação de estações de compressão ao longo do trajeto do gasoduto para manter a pressão do gás em uma faixa

$\begin{array}{llllll}\text { Caminhos de Geografia } & \text { Uberlândia - MG } & \text { v. 19, n. 67 } & \text { Set/2018 } & \text { p. 234-252 } & \text { Página } 236\end{array}$


operacional. A capacidade de transporte de gás natural por um gasoduto é função do diâmetro das tubulações e da pressão. Quanto maior o diâmetro da tubulação, maior a capacidade de transporte. Da mesma forma, quanto maior a pressão, maior será o volume de gás transportado por diâmetro de tubulação. O sistema de transporte pode ser formado por um único duto ligando o ponto de entrega a um ponto de consumo, por um duto com diversos pontos de entrega ao longo do caminho, ou por uma rede de dutos interconectados, ligando diversas áreas produtoras a diversos centros consumidores.

Tabela 1: Leis e Resoluções da ANP

\begin{tabular}{|c|c|}
\hline LEIS E RESOLUÇÕES ANP & RESUMO \\
\hline LEI 9.478, DE 06/08/1997 & $\begin{array}{l}\text { Dispõe sobre a política energética nacional, as atividades relativas ao monopólio do petróleo, institui o Conselho } \\
\text { Nacional de Política Energética e a Agência Nacional de Petróleo e dá outras providências. }\end{array}$ \\
\hline LEI 11.909, DE 04/03/2009 & $\begin{array}{l}\text { Dispõe sobre as ativades relativas ao transporte de gás natural, de que trata o art. } 177 \text { da Constituição Federal, bem } \\
\text { como sobre as atividades de tratamento, processamento, estocagem, liquefação, regaseificação e comercialização de } \\
\text { gás natural. }\end{array}$ \\
\hline DECRETO 7.382, DE 2/12/2010 & $\begin{array}{l}\text { Regulamenta os Capítulos I a VI e VIII da Lei no } 11.909 \text {, de } 4 \text { de março de } 2009 \text {, que dispõe sobre as atividades } \\
\text { relativas ao transporte de gás natural, de que trata o art. } 177 \text { da Constituição Federal, bem como sobre as atividades } \\
\text { de tratamento, processamento, estocagem, liquefação, regaseificação e comercialização de gás natural. }\end{array}$ \\
\hline RESOLUÇÃO 6, DE 3/2/2011 & $\begin{array}{l}\text { Aprovação do Regulamento Técnico de Dutos Terrestres para Movimentação de Petróleo, Derivados e Gás Natural - } \\
\text { RTDT, relativos aos oleodutos e gasodutos autorizados ou concedidos a operar pela ANP. }\end{array}$ \\
\hline RESOLUÇÃO 44, DE 18/8/2011 & $\begin{array}{l}\text { Atribuição da ANP instruir processo com vistas à declaração de utilidade pública, para fins de desapropriação e } \\
\text { instituição de servidão administrativa, das áreas necessárias à exploração, desenvolvimento e produção de petróleo e } \\
\text { gás natural, construção de refinarias, de dutos e de terminais. }\end{array}$ \\
\hline RESOLUÇÃO 35, DE 13/11/2012 & $\begin{array}{l}\text { Estabelece a regulamentação do uso por terceiros interessados, de dutos de transporte destinados à movimentação } \\
\text { de petróleo, seus derivados e biocombustíveis, existentes ou a serem construídos. }\end{array}$ \\
\hline RESOLUÇÃO 42, DE 10/12/2012 & $\begin{array}{l}\text { Regras para compartilhamento de servidões administrativas e faixas de servidão do setor de petróleo, seus derivados, } \\
\text { gás natural e biocombustíveis. }\end{array}$ \\
\hline RESOLUÇÃO 15, DE 14/03/2014 & $\begin{array}{l}\text { Resolução estabelece critérios para cálculo das tarifas de transporte referentes aos serviços de transporte firme, } \\
\text { interruptível e extraordinário de gás natural; e procedimento para a aprovação das propostas de tarifa de transporte de } \\
\text { gás natural encaminhadas pelos transportadores para os gasodutos de transporte objeto de autorização. } \\
\text { Regulamento que trata dos procedimentos para a realização de licitação para a concessão da atividade de transporte }\end{array}$ \\
\hline \multicolumn{2}{|l|}{ RESOLUÇÃO 39, DE 30/07/2014 } \\
\hline RESOLUÇÃO 52, DE 2/12/2015 & $\begin{array}{l}\text { Fica estabelecida a regulamentação para a construção, a ampliação e a operação de instalações de movimentação de } \\
\text { petróleo, seus derivados, gás natural, inclusive liquefeito (GNL), biocombustíveis e demais produtos regulados pela } \\
\text { ANP. }\end{array}$ \\
\hline RESOLUÇÃO 11, DE 16/3/2016 & $\begin{array}{l}\text { Dispões sobre a Oferta de Serviços, Cessão de Capacidade Contratada, Troca Operacional de Gás Natural, Aprovação } \\
\text { e Registro dos Contratos de Servço de Transporte de Gás Natural - Promoção dos Processos de Chamada Pública } \\
\text { para Contratação de Capacidade de Transporte de Gás Natural e dá outras providências. }\end{array}$ \\
\hline PORTARIA 170, DE 26/11/1998 & $\begin{array}{l}\text { Estabelece a regulamentação para a construção, a ampliação e a operação de instalações de transporte ou de } \\
\text { transferência de petróleo, seus derivados, gás natural, inclusive liquefeito, biodiesel e misturas óleo diesel/biodiesel. }\end{array}$ \\
\hline PORTARIA 115, DE 05/7/2000 & $\begin{array}{l}\text { Fica regulamentado, o uso, por terceiros interessados, de dutos de transporte destinados à movimentação de } \\
\text { petróleo e seus derivados, existentes ou a serem construídos, mediante remuneração adequada ao titular das } \\
\text { instalações. }\end{array}$ \\
\hline PORTARIA 255, DE 16/11/2000 & $\begin{array}{l}\text { Fica regulamentado, o uso por terceiros interessados, dutos de transporte de petróleo e seus derivados, cuja } \\
\text { extensão seja inferior a } 15 \mathrm{~km} \text { (quinze quilômetros) e que não tenham origem em área de produção de petróleo e gás } \\
\text { natural. }\end{array}$ \\
\hline PORTARIA 125, DE 05/08/2002 & $\begin{array}{l}\text { Dispõe sobre os procedimentos de natureza preventiva a serem adotados no acompanhamento de obras com } \\
\text { interferência em faixa de domínio de dutos de petróleo, seus derivados ou gás natural. }\end{array}$ \\
\hline
\end{tabular}

Fonte: Elaborado pelo autor.

No Brasil, o arcabouço legal e regulatório faz uma divisão das redes, atribuindo o transporte (ou movimentação) por meio de duto como competência da União, e atribuindo os serviços locais de gás canalizado à competência dos Estados.

Freitas (2004) explica que uma das particularidades das indústrias de infraestrutura é o fato de seus ativos serem indivisíveis, ou seja, eles só são eficientes se forem construídos como um todo. O custo

$\begin{array}{llllll}\text { Caminhos de Geografia } & \text { Uberlândia - MG } & \text { v. 19, n. } 67 & \text { Set/2018 } & \text { p. 234-252 } & \text { Página } 237\end{array}$


de implantação dos ativos de infraestrutura costuma ser muito elevado e o prazo de maturação desses investimentos muito longo. Em contrapartida, uma vez realizados os investimentos, os custos marginais de fornecimento do serviço são muito baixos. O modal dutoviário é caracterizado como indústria de rede, nas quais as distintas atividades da cadeia são conectadas umas às outras, sendo premente a coordenação entre elas para que haja eficiência na prestação do serviço. Os dutos fazem parte de uma etapa da mobilidade da mercadoria. Desde a extração do petróleo até os postos de abastecimento o combustível passa por várias etapas de circulação, fazendo a interligação entre terminal marítimo, refinarias e terminais de abastecimento.

De acordo com Sousa (2005), para haver uma utilidade no modal dutoviário, onde o custo não seja alto, é importante ter uma circulação ampla de combustíveis, isto é, quanto menos mercadorias em circulação maiores serão os custos. Para não haver altos custos no transporte dutoviário é necessário que o mercado brasileiro e o consumo de derivados de petróleo estejam estabilizados. Outra característica é a economia de transmissão em larga escala. Quanto maior o mercado e maior o diâmetro do oleoduto menor serão os custos no transporte. A existência de rendimentos crescentes de escala é, portanto, característica do modal dutoviário.

Quando comparado com os cincos modais básicos de transportes, ferroviário, rodoviário, hidroviário, dutoviário e aéreo, conforme observado na Tabela 2, o modal dutoviário têm o mais alto custo fixo e o mais baixo custo variável entre os modais de transporte. Os altos custos fixos resultam de sua estrutura física, como faixas de dutos, construção e montagem, estações de controle, e da capacidade de bombeamento. Uma vez que os dutos não necessitam de muita mão de obra, o custo operacional variável é extremamente baixo depois que ele é construído.

Tabela 2: Estrutura de Custos de Modais

\begin{tabular}{|c|c|c|}
\hline Modal & Custos Fixos & Custos Variáveis \\
\hline Ferroviário & $\begin{array}{c}\text { Alto } \\
\text { (equipamentos, terminais, trilhos, etc) }\end{array}$ & Baixo \\
\hline Rodoviário & $\begin{array}{c}\text { Baixo } \\
\text { (estradas prontas e fornecidas pelo dinheiro } \\
\text { público) }\end{array}$ & $\begin{array}{c}\text { Médio } \\
\text { (combustível, manutenção etc.) }\end{array}$ \\
\hline Hidroviário & $\begin{array}{c}\text { Médio } \\
\text { (Navios e equipamentos) }\end{array}$ & $\begin{array}{c}\text { Baixo } \\
\text { (capacidade de transportar grande quantidade } \\
\text { de carga) }\end{array}$ \\
\hline Dutoviário & $\begin{array}{l}\text { Mais alto de todos } \\
\text { (dutos, faixas de domínio, construção, necessidade de } \\
\text { estações de controle ecapacidade de bombeamento) }\end{array}$ & $\begin{array}{c}\text { Mais baixo de todos } \\
\text { (Não há custo de mão de obra significativo) }\end{array}$ \\
\hline Aeroviário & $\begin{array}{c}\text { Baixo } \\
\text { (aeronaves e sistemas de manuseio e carga) }\end{array}$ & $\begin{array}{c}\text { Alto } \\
\text { (combustível, mão de obra, manutenção etc.) }\end{array}$ \\
\hline
\end{tabular}

Fonte: Bowersox et al. (2014).

Sousa (2005) explica que os custos de transmissão em dutos dependerão da viscosidade do produto. Quanto mais viscoso for o produto, tanto maior será o custo por tonelada - quilômetro para movimentá-lo. Destaca também sobre as condições do relevo, pois, o custo também varia de acordo com as condições físicas do trajeto. Nestas circunstâncias, as tarifas de transporte são determinadas basicamente em função do fator de utilização de cada linha, das características do produto transportado, especialmente a viscosidade, e da distância entre o ponto de carregamento e o ponto de descarga. Normalmente, as tarifas estabelecidas pelo transportador incluem uma parcela de custo fixo e uma de custo variável, sendo esta última função da distância e do tipo de produto.

Para Vassallo (2015) os custos diferenciam-se por questões como consumo de combustível e outros insumos de desgaste, quantidade e capacitação da mão de obra, custos fixos de equipamentos, leasing, entre outras. Tais custos são bastante diversos entre os modais, por esse motivo os preços dos fretes definidos em termos de reais por tonelada transportada por quilômetro diferem em até 60 vezes de modal para o outro, conforme mostra a Tabela 3 (numerador nas colunas e denominador

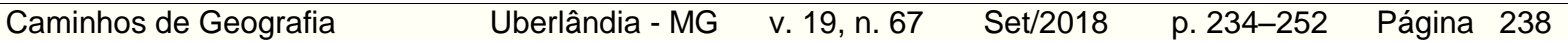


nas linhas). $O$ transporte rodoviário pode ser de 4,5 até 5,7 vezes mais caro que o dutoviário que se apresenta como o modal de menores custos.

Tabela 3: Custos relativos de frete

\begin{tabular}{lccccc}
\hline & Rodoviário & Ferroviário & Aquaviário & Dutoviário & Aeroviário \\
\hline Rodoviário & 1 & 0,2 até 0,4 & 0,2 até 0,3 & 0,2 até 0,2 & 7,4 até 11,4 \\
Ferroviário & 2,5 até 5,7 & 1 & 0,7 até 1,3 & 0,6 até 1 & 20 até 42,2 \\
Aquaviário & 3,6 até 4,4 & 0,8 até 1,5 & 1 & 0,7 até 0,8 & 30 até 40,6 \\
Dutoviário & 4,5 até 5,7 & 1 até 1,8 & 1,2 até 1,5 & 1 & 36 até 61,5 \\
Aeroviário & 0,09 até 0,13 & 0,02 até 0,05 & 0,02 até 0,03 & 0,02 até 0,03 & 1 \\
\hline
\end{tabular}

Fonte: Vassalo (2015)

Conforme apresentado na Tabela 3, uma vez implantado o modal dutoviário, o modal ferroviário é o único que pode apresentar preços dos fretes, em termos de reais por tonelada transportada por quilômetro, compatíveis ao modal dutoviário.

\section{A GEOPOLÍTICA DOS DUTOS}

Kandiyoti (2012) esclarece que vastas quantidades de combustíveis são transportados todos os dias, ao longo de grandes distâncias, muitas vezes através de continentes inteiros. Apesar das preocupaçãoes sobre a poluição ambiental e aquecimento global, a maioria das nações continuam a consumir quantidades crescentes de combustíveis fósseis, para que suas economias possam funcionar e crescer. Mas a distribuição geográfica de petróleo e gás natural é desigual. Com rápida expansão do comércio, o transporte de longo curso destes combustíveis se expandiu em uma indústria importante. A maior parte do petróleo e gás é transportado em navios petroleiros ou por dutos. Muitos dutos, precisam atravessar territórios pertencentes a "outros" Estados, por vezes, uma sucessão de outros Estados, aí que os problemas começam frequentemente. A natureza vital do transporte de combustível está entre importantes elementos geopolíticos que agora regulam as relações entre os Estados. Projetos de transporte de energia pode ser impulsionado pela demanda e orientada pela física (volume, pressão, temperatura, etc..), mas, em última análise, eles são determinados pelo contexto geopolítico.

Rennó e Lemgruber (2009) relatam que a utilização de dutos na indústria de óleo e gás data da primeira metade do século XIX. Entre 1806 e 1820, em cidades da Inglaterra e dos Estados Unidos tem-se registro do lançamento de tubulações de madeira para alimentação de sistemas de iluminação pública com gás manufaturado, produzido a partir do carvão. A partir de então, esses sistemas se expandiram rapidamente para suprimento de iluminação a gás a consumidores comerciais e industriais, dando origem aos primeiros sistemas de distribuição de gás para as principias metrópoles da época.

Yergin (2012) descreve que desde as primeiras descobertas do petróleo, na cidade de Oil City no Estados Unidos, os carroceiros passavam pelas estradas com sua carga de barris. Tendo uma condição monopolística, cobravam uma exorbitância; saía mais caro deslocar um barril por uns poucos quilômetros de estrada até uma estação de trem, do que transportá-lo por ferrovia desde o oeste da Pensilvânia até Nova York. O poder dos carroceiros levou a um esforço para desenvolver uma engenhosa alternativa: o transporte por oleodutos. Entre 1863 e 1865, os oleodutos de madeira provaram que poderiam transportar o óleo de modo muito mais eficiente e barato. Em 1866, a maioria dos poços em Oil Regions estava acoplada a oleodutos que desembocavam no sistema de coleta de um oleoduto maior, ligado às ferrovias.

No Brasil, uma série de instalações de transporte foram sendo implantadas nas várias regiões do País, por intermédio de dutos, terminais e navios, objetivando atender a necessidades específicas de cada região, tais como, escoar petróleo de produção nacional, escoar derivados produzidos pelas refinarias, abastecer refinarias com petróleo nacional ou importado, abastecer a rede de distribuição

$\begin{array}{llllll}\text { Caminhos de Geografia } & \text { Uberlândia - MG } & \text { v. 19, n. 67 } & \text { Set/2018 } & \text { p. 234-252 } & \text { Página } 239\end{array}$


de derivados e outros produtos e armazenar e estocar petróleo, derivados e outros produtos líquidos ou gasosos.

Leite (2014) relata que o governo do presidente Eurico Dutra deu início, em 1947, à elaboração de uma legislação do petróleo já baseada na nova Constituição, de cujos trabalhos resultou proposta denominada Estatuto do Petróleo. Tudo continuava até aí sob a coordenação do Conselho Nacional do Petróleo, ou CNP, que foi o órgão governamental brasileiro responsável pela definição da política petrolífera no período de 1939 a 1960. O conselho foi a primeira iniciativa para estruturar e regulamentar a exploração de petróleo no Brasil. Rennó e Lemgruber (2009) explicam que a atividade dutoviária no Brasil remonta à autorização concedida em 1948 pelo Conselho Nacional do Petróleo (CPN), à Estrada de Ferro Santos-Jundiaí, para a construção de uma rede de oleodutos entre as cidades de Santos e São Paulo.

Com o novo período de industrialização decorrente da política desenvolvimentista do presidente Juscelino Kubitschek (1956 a 1961), e a ênfase dada pelo seu governo ao programa da indústria automobilística e de construção de rodovias, cresceu o consumo de derivados de petróleo, com impulso que perdurou no período dos presidentes Jânio Quadros (1961) e João Goulart (1961 a 1964). Em consequência, os derivados de petróleo surgem como principal insumo energético em 1969. Com a ampliação do parque de refino brasileiro na década de 60 , ocorreu grande incremento em projetos de novos dutos, necessários tanto para o suprimento de petróleo, matéria-prima das refinarias, quanto para, uma vez processado este último, o posterior escoamento dos seus derivados para os pontos de consumo. Ainda nos anos 60 entraram em operação os oleodutos Rio de JaneiroBelo Horizonte, em Sergipe, Rio Grande do Sul e São Paulo.

Nos anos 70, entraram em atividade o oleoduto Angra dos Reis-Refinaria de Duque de Caxias (REDUC), e outros no Rio de Janeiro e em São Paulo. Na administração do general Ernesto Geisel (1974-1979), a política de investimentos na Petrobras deu preferência às áreas de refino, transporte e distribuição, aparentemente com objetivo de lucro imediato para a empresa, quase sem riscos, que provinham pelas atividades de refino, transporte marítimo, terminais e dutos, na maioria com preços regulados pelo próprio governo. Contudo, entre 1973 e 1974, o preço médio corrente do petróleo importado pelo Brasil iria elevar-se de US\$ 3,66 para US\$12,2 por barril, o que provocou revisão desta política, especialmente no Governo João Figueiredo (1979 a 1985), que retornou à tradição de maiores investimentos nas áreas de pesquisa e desenvolvimento da produção de petróleo. Segundo Santos et al. (2002) durante os anos 1970 e 1980 a alternativa de importar gás natural da Argentina e Bolívia foi descartada. A grande politização da questão energética depunha contra essa opção em um país sob regime militar, ditatorial e que levava em conta os preceitos de segurança energética, autossuficiência e nacionalismo.

Nos anos 80, passou a operar um novo oleoduto Rio de Janeiro-Belo Horizonte, e teve lugar a construção dos primeiros grandes gasodutos, como o gasoduto Nordestão, que percorre 424 quilômetros entre Guamaré-RN e Cabo de Santo Agostinho-PE, além do Rio Grande do Norte, passa por Paraíba e Pernambuco e outros gasodutos para transporte do gás produzido na Bacia de Campos até o Rio de Janeiro.

Nos anos 90 foram construídos dutos destinados ao transporte de derivados entre São Paulo-Brasília, Paraná-Santa Catarina, Recôncavo-Sul da Bahia, e diversos outros gasodutos foram incorporados ao sistema dutoviário brasileiro, acompanhando o desenvolvimento do País e o crescimento da produção de petróleo e gás natural, além de várias instalações offshore. No final dos anos 1990, o gás natural voltou definitivamente à ordem do dia no Brasil. Com o crescimento da produção nacional de petróleo, tornou-se imperativo maior aproveitamento do gás associado, já que as pressões são crescentes contra a queima inútil de gás na boca do poço. Por outro lado, mostraram-se ainda mais promissoras as descobertas de gás não associado no país, mas principalmente na Bolívia e Argentina.

Merece destaque a construção do gasoduto Bolívia-Brasil, no período de 1997 a 2000, com 3.150 quilômetros de comprimento - dos quais 557 quilômetros em território boliviano, interligando a cidade de Santa Cruz de La Sierra a Puerto Suarez (fronteira Bolívia-Brasil); e 2.593 quilômetros em solo brasileiro, atravessando os estados de Mato Grosso do Sul; São Paulo; Paraná; Santa Catarina e Rio Grande do Sul. O gasoduto Bolívia-Brasil (Gasbol) constitui a primeira grande iniciativa de ancorar a integração energética do Cone Sul da América do Sul por meio do gás natural. O Gasbol foi o maior empreendimento energético da América do Sul nos anos 1990, após mais de vinte anos de negociações, foi construído o maior gasoduto da América do Sul. O Gasbol foi, primeiramente, um projeto geopolítico, baseado no forte desejo do Presidente Fernando Henrique de incorporar a Bolívia

\begin{tabular}{llllll}
\hline Caminhos de Geografia & Uberlândia - MG & v. 19, n. 67 & Set/2018 & p. 234-252 & Página 240
\end{tabular}


ao Mercosul. Além do mais, o projeto deveria consolidar a expansão internacional do Brasil como potência regional. O Gasbol, em particular, foi um projeto de dois governos, cuja fundamentação econômica ainda não estava completamente justificada no momento de sua construção, devendo, portanto, ser interpretado como um projeto "geopolítico" de Brasil e Bolívia. A construção do gasoduto Bolívia-Brasil serve de referência para outros empreendimentos de interligação regional. A obra incitou um tipo de "febre do gás" na região do Cone Sul da América do Sul, estimulando, naturalmente, um verdadeiro espírito de integração gasífera na região.

Finalmente, em 2009 teve início a produção de petróleo no pré-sal. As descobertas no pré-sal estão entre as mais importantes em todo o mundo na última década. A província pré-sal é composta por grandes acumulações de óleo leve, de excelente qualidade e com alto valor comercial. Uma realidade que coloca o Brasil em uma posição estratégica frente à grande demanda de energia mundial. $\mathrm{A}$ produção diária de petróleo no pré-sal passou da média de aproximadamente 41 mil barris por dia, em 2010, para o patamar de 1 milhão de barris por dia em meados de 2016. Um crescimento de quase 24 vezes (PETROBRAS, 2017). No desenvolvimento do pré-sal, há necessidade de expansão da cadeia produtiva, em particular, do segmento de dutos, que requer novas tecnologias e soluções para incremento da logística do petróleo, seus derivados e gás natural.

\section{ESTRUTURA DE MERCADO E BARREIRAS DE ENTRADA}

Mercado é definido por Pindyck e Rubinfeld (2006) como "conjunto de compradores e vendedores que determinam juntos os preços de cada um dos bens". Os mercados estão no centro da atividade econômica, e muitas das questões mais interessantes da economia estão relacionadas com o modo de funcionamento dos mercados.

Por estrutura de mercado, Vasconcellos e Oliveira (2011) classificam o ambiente competitivo existente, que vai desde um mercado perfeitamente competitivo, passando por um cenário de oligopólio até um mercado monopolizado, conforme existam respectivamente muitas, poucas ou apenas uma firma atuando no mercado de um bem.

Vasconcellos e Oliveira (2011) explicam que Monopólio "existe quando apenas uma empresa produz uma mercadoria sem substitutos próximos". Explicam ainda que a existência de monopólio depende da existência de barreiras à entrada de firmas concorrentes, podendo ser barreiras legais, controle do fornecimento de matérias-primas ou barreiras de escala.

Segundo Salomão Filho (1998) existem duas as noções existentes a respeito do conceito econômico de monopólio natural. Monopólio natural é aquela situação de monopólio criada naturalmente e não em função da ação dos agentes econômicos direcionada à sua constituição. Tal situação se verifica naqueles setores em que a competição é impossível, física ou economicamente. Causas da impossibilidade física podem ser a existência de fontes de insumos únicas ou exclusivas ou, ainda, a existência de uma tecnologia exclusiva protegida por patente ou por segredo industrial eficazmente protegido. Já a segunda é a impossibilidade econômica, decorrente de características particulares inerentes àquele ramo específico da indústria que tornam a competição ruinosa ou autodestrutiva.

Pinto Junior e Silveira (1999) indicam condições necessárias para a caracterização de uma indústria em regime de monopólio natural como vender um produto essencial, ocupar uma localização favorável para produzir, vender um produto de difícil estocagem, beneficiar-se de economias de escala e obrigação de fornecimento. Listam também, características técnico-econômicas em industrias consideradas monopólios naturais com pesados investimentos em redes físicas (indústrias de rede), em boa parte irrecuperáveis no caso de saída; longos prazos de maturação; escala econômica elevada para os mercados onde operavam e relevante interesse social.

No transporte dutoviário, mesmo que fosse livre a construção de uma nova linha, os custos para que um novo competidor entre no mercado por meio da construção de um duto alternativo são maiores em relação aos da empresa operando o duto já existente, à qual basta ampliar as instalações e capacidade de transporte já existente. Sob circunstâncias descritas anteriormente, a exploração comercial de um duto tem características de um monopólio natural, com as implicações decorrentes, com pesadas barreiras à entrada e à saída, que justificam a presença ativa do Estado como regulador e operador.

Melo, Forte e Sousa Filho (2014) descrevem que a primeira publicação que se tem com a expressão "barreiras de entrada", é de Bain, onde as consideram correguladores de conduta e desempenho das atividades empresariais. Desde então, muito já foi discutido sobre o assunto, em diferentes mercados

$\begin{array}{llllll}\text { Caminhos de Geografia } & \text { Uberlândia - MG } & \text { v. 19, n. 67 } & \text { Set/2018 } & \text { p. 234-252 } & \text { Página } 241\end{array}$


e abordagens, como impactos que novos entrantes causam na rentabilidade de empresas já atuantes no mercado, vantagens de custo das empresas já estabelecidas, inovação e a natureza da estrutura de custos.

Para Porter (2004) devem ser consideradas também sete tipos de barreiras que o próprio mercado impõe e que, ao adotá-las, está configurada uma estratégia de competição, conforme relacionadas a seguir.

Economia de Escala. Economias de escala referem-se aos declínios nos custos unitários de uma operação (ou produto), à medida que o volume absoluto por período aumenta. Economias de escala detêm a entrada forçando a empresa entrante a ingressar em larga escala e arriscar-se a uma forte reação das empresas existentes ou a ingressar em pequena escala e sujeitar-se a uma desvantagem de custo.

Diferenciação de Produto. Significa que as empresas estabelecidas têm sua marca identificada e desenvolvem um sentimento de lealdade em seus clientes.

Necessidades de Capital. A necessidade de investir vastos recursos financeiros de modo a competir cria uma barreira de entrada.

Custos de Mudança. Uma barreira de entrada é criada pela presença de custos de mudança, ou seja, custos com que se defronta o comprador quando muda de um fornecedor de produto para outro. Os custos de mudança podem incluir custos de um novo treinamento dos empregados, custo de novo equipamento auxiliar, custo e tempo para testar ou qualificar uma nova fonte ou novo projeto do produto.

Acesso aos Canais de Distribuição. Pode ser criada barreira de entrada pela necessidade de a nova entrante assegurar a distribuição para seu produto.

Desvantagens de Custo Independentes de Escala. As empresas estabelecidas podem ter vantagens de custos impossíveis de serem igualadas pelas entrantes potenciais, qualquer que seja o seu tamanho e as economias de escala obtidas. As vantagens mais críticas são fatores como os seguintes:

- tecnologia patenteada do produto;

- $\quad$ acesso favorável às matérias-primas;

- localização favoráveis;

- $\quad$ subsídios oficiais; e

- $\quad$ curva de aprendizagem ou de experiência.

Politica Governamental. O governo pode limitar ou mesmo impedir a entrada em indústrias com controles como licenças de funcionamento e limites ao acesso a matérias-primas. Industrias regulamentadas são exemplos óbvios. Por exemplo, as exigências quanto ao controle da poluição podem aumentar o capital necessário à entrada e à sofisticação tecnológica requerida, e mesmo à escala ótima das instalações.

\section{ANÁLISE DO MODAL DUTOVIÁRIO FRENTE À LEGISLAÇÃO}

Nas duas últimas décadas, a indústria do modal dutoviário destinado ao transporte de petróleo e gás natural no país vem passando por reformas que objetivam a regulação das atividades naturalmente monopólicas, sendo os dois marcos principais destas reformas a Lei oㅜ 9.478/1997 (Lei do Petróleo) e a Lei no 11.909/2009 (Lei do Gás), esta última regulamentada pelo Decreto № 7.382/2010 (BRASIL, 2010).

Para Ferraro (2010) a aprovação da lei no 9.478 de 1997 é um reflexo de mudança do papel do Estado na indústria de petróleo e gás natural. A lei do petróleo, como é conhecida a lei no 9.478 , quebrou o monopólio da Petrobras ao regulamentar que a união poderá contratar empresas estatais ou privadas para a realização das atividades das quais possui o monopólio de exploração. Ademais, é criada a Agência Nacional de Petróleo (ANP) e criado o Conselho Nacional de Política Energética com a função de assessoramento da Presidência da República no estabelecimento de políticas e diretrizes para o setor energético.

$\begin{array}{llllll}\text { Caminhos de Geografia } & \text { Uberlândia - MG } & \text { v. 19, n. 67 } & \text { Set/2018 } & \text { p. 234-252 } & \text { Página } 242\end{array}$


Explica ainda que o objetivo do governo ao aprovar a lei $n^{\circ} 9.478$ foi introduzir pressões competitivas na indústria de petróleo e gás natural a partir de estímulos ao ingresso de novos agentes privados. A finalidade da lei, nesse sentido, era fazer com que os agentes privados realizassem os investimentos que até então eram realizados pelo governo Federal por meio da Petrobras.

A respeito do modal dutoviário, a Lei no 9.478, de 06/08/1997 dispõe sobre o exercício do Monopólio da atividade de dutos no Artigo 4:

Constituem monopólio da União, nos termos do art. 177 da Constituição Federal, as seguintes atividades:[...]

IV - o transporte marítimo do petróleo bruto de origem nacional ou de derivados básicos de petróleo produzidos no País, bem como o transporte, por meio de conduto, de petróleo bruto, seus derivados e de gás natural. (BRASIL, 1997).

No Artigo 5, a Lei trata das atividades econômicas do modal dutoviário que serão reguladas e fiscalizadas pela União e poderão ser exercidas mediante concessão ou autorização por empresas constituídas sob as leis brasileiras, com sede e administração no País.

As empresas autorizadas a construir e operar instalações de transporte dutoviário, diz o Artigo 56:

Observadas as disposições das leis pertinentes, qualquer empresa ou consórcio de empresas que atender ao disposto no art. 5ํำ poderá receber autorização da ANP para construir instalações e efetuar qualquer modalidade de transporte de petróleo, seus derivados e gás natural, seja para suprimento interno ou para importação e exportação (BRASIL, 1997).

Com a promulgação da Lei $n^{\circ} 11.909$, de 4 de março de 2009, chamada de a "Lei do Gás", regulamentada pelo Decreto $\mathrm{n}^{\mathrm{0}}$ 7.382, de 02 de dezembro de 2010, foi estabelecido um novo marco regulatório para a indústria do gás natural no país. O foco da lei 11.909 é o midstream uma vez que tanto a produção quanto a distribuição continuam sendo reguladas respectivamente pela lei $9.478 \mathrm{e}$ pelo Artigo 25 da Constituição Federal. As principais mudanças trazidas pela nova lei concentram-se, principalmente, na regulação do segmento de transporte de gás natural.

A Lei do Gás introduziu importantes inovações no arcabouço regulatório referente ao segmento de transporte de gás natural, tanto no que se refere ao processo de autorização da construção e/ou ampliação de novos gasodutos, quanto à determinação da tarifa aplicável ao serviço de transporte.

No que se refere à construção de novos gasodutos, é importante ressaltar que a "Lei do Gás" inseriu no arcabouço jurídico da indústria do gás o regime de concessão precedido de licitação para gasodutos de transporte. Não obstante, manteve o regime de autorização, aplicável aos dutos existentes, àqueles que tenham obtido autorização de construção da ANP e àqueles que tenham iniciado processo de licenciamento ambiental até a data de publicação da Lei (Art. 30 , §2º da Lei no 11.909/2009). Ademais, o regime de autorização também foi mantido para novos gasodutos de transporte que envolvam acordos internacionais (Art. 3ㅜ, da Lei ํo 11.909/2009).

O período dos contratos de concessão será de 30 anos, contado da data de assinatura do contrato, podendo ser prorrogado no máximo por igual período. Extinta a concessão, os bens destinados à exploração da atividade de transporte serão incorporados ao patrimônio da União, mediante justa e prévia indenização.

\section{REGULAÇÃO DE OLEODUTOS E GASODUTOS}

Até 2009, o arcabouço regulatório da indústria do modal dutoviário, era definido pela Lei 9.478 e pelas portarias e resoluções da ANP conforme apresentado na seção anterior, a Lei 9.478 delega à ANP a responsabilidade pela regulação das atividades de transporte de petróleo, seus derivados e gás natural, sendo feito o exercício dessas atividades pela agência reguladora por regulamentações (definidas na lei ou por portarias da ANP) ou por meio do poder de fiscalização e monitoramento concedido à Agência.

Apesar das diferenças técnicas e econômicas entre os serviços de transporte de gás natural e o serviço de transporte de petróleo e derivados, o artigo 56 da Lei 9.478 trata as atividades de forma igual. Nesse sentido, estabelece-se a autorização como regime jurídico da atividade de transporte de hidrocarbonetos líquidos e gasosos. 
Em 2009, foi aprovada e sancionada a lei 11.909 que redefine o arcabouço regulatório da indústria de gás natural, em particular para o segmento de transporte. Ferraro (2010) explica que a lei 11.909 redefiniu e delimitou o escopo de atuação do Ministério de Minas e Energia (MME) e da ANP na regulação e no planejamento do transporte dutoviário de gás natural. No novo arcabouço institucional, - MME passou a exercer as seguintes funções: realização de estudos de expansão da malha dutoviária, subsidiado pela EPE- Empresa de Planejamento Energético; proposta dos gasodutos de transporte a serem construídos ou ampliados; estabelecimento das diretrizes do processo de contratação das empresas de transporte; estabelecimento do período de exclusividade para os carregadores iniciais; e determinação da utilização de parcerias públicas e privadas (PPP) e dos recursos da Contribuição de Intervenção no Domínio Econômico (CIDE) para a construção de gasodutos de transporte considerados de relevante interesse público.

Desta forma, Cordeiro et al. (2012) sintetiza o processo para a construção de um novo gasoduto, a qual contém as seguintes etapas:

a) Proposição do empreendimento por parte do MME (que pode ser provocado por terceiros a propor determinado projeto de gasoduto);

b) Realização de Chamada Pública (Art. 2ํㅡㄹ inciso VII) para a identificação da capacidade do gasoduto, que será dimensionado conforme o interesse manifestado pelos carregadores durante o processo. Ao fim da Chamada Pública os carregadores para os quais for alocada capacidade assinarão com a ANP um Termo de Compromisso de compra de capacidade;

c) Licitação conduzida pela ANP para a escolha do transportador, que será responsável por construir e operar o gasoduto;

d) Assinatura de contrato de concessão de transporte de gás natural entre o transportador vencedor da licitação e a ANP; e

e) Assinatura de contratos de transporte de gás natural entre o transportador, vencedor da licitação, e os carregadores, vencedores da Chamada Pública.

Pereira, Silva e Venezia (2014) complementam que no âmbito dos seus poderes regulatórios, a ANP emite portarias, que visam regulamentar leis ou decretos, instruções normativas, que visam complementar outros atos normativos, e resoluções, que são atos normativos decorrentes de competências privativas. A Figura 1 indica as etapas para a construção de novos gasodutos de transporte sob regime de outorga de concessão, apresentando o responsável por cada uma delas.

Figura 1: Etapas para a Construção de Novos Gasodutos de Transporte sob Regime de Outorga de Concessão

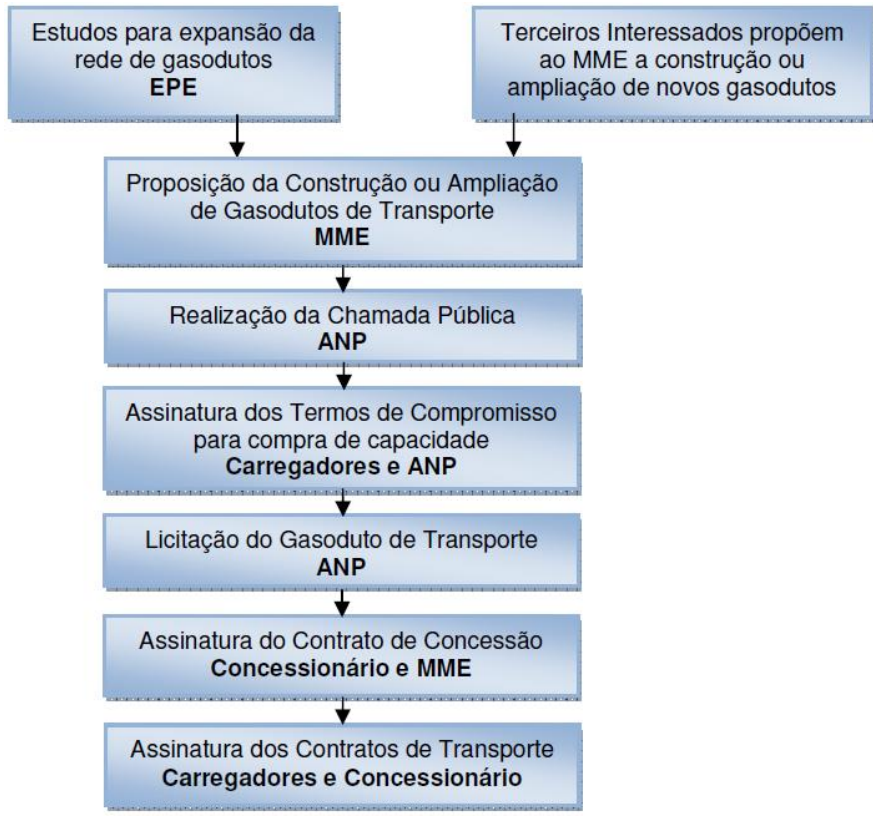

Fonte: Cecchi (2012). 
Durante a Chamada Pública, a ANP é responsável por fixar a tarifa máxima aplicável aos carregadores interessados em contratar capacidade de transporte, devendo estes assinarem com a ANP um Termo de Compromisso de compra de capacidade, em atendimento a outra inovação trazida pela Lei no 11.909/2009, que diz respeito à determinação da tarifa aplicável ao serviço de transporte para os dois regimes de outorga (concessão e autorização) que, embora distintos, exigem a intervenção direta da ANP.

No caso do regime de concessão, cabe à ANP estabelecer a tarifa aplicável, com base no resultado do processo licitatório que antecede a concessão (Conforme § do Art. 13 da Lei no 11.909/2009). No caso do regime de autorização, o cálculo da tarifa proposta pelo transportador deve obedecer aos critérios estabelecidos pela ANP e ser submetido à aprovação da Agência (Segundo o disposto no Art. 28 da Lei n 11.909/2009) em atendimento ao disposto no §3ํ do Art. 5ํㅡ, da Lei nº 11.909/2009 (BRASIL, 2009).

Desta maneira, para os novos gasodutos, haverá uma definição clara da formação da tarifa de transporte de gás natural, e consequentemente, será possível separar de forma clara e transparente os valores referentes ao transporte de gás natural e à molécula, quando da comercialização do gás natural.

Para Ferraro (2010), algumas mudanças introduzidas pela lei $n \cong 11.909$ contribuem sensivelmente para a redução de parte dos riscos do investimento em novos gasodutos. Entre estas mudanças pode-se destacar o estabelecimento da concessão como regime jurídico da atividade de transporte, a regulação dos contratos de concessão, a adoção de mecanismos de chamada pública com a assinatura de termos de compromisso, e a definição e limitação do escopo de atuação de cada agente do poder público. O regime de concessão desfruta de uma grande segurança jurídica que faz dele um instrumento jurídico mais adequado para as atividades que exigem elevados investimentos em ativos específicos. Pinto (2006) explica que o concessionário deve assumir o principal risco da exploração comercial do serviço, o risco de que a receita auferida por ele será suficiente para cobrir seus custos, ou seja, esse risco consiste em fazer com que o custo e despesas da prestação do serviço sejam inferiores à receita obtida com a cobrança de tarifa, de modo a gerar lucros suficientes para remunerar o capital empregado no negócio. Portanto, desde que esse risco seja transferido para concessionária, estará atendida a definição de concessão prevista no artigo $2^{\circ}$, da Lei 8.987/95.

Pela Lei do Petróleo (Lei $n^{\circ}$ 9.478) o regime de outorga das atividades de transporte de petróleo e seus derivados ocorre por autorização. Segundo Di Pietro (2015) autorização é o ato administrativo unilateral e discricionário. $\mathrm{O}$ ato discricionário é aquele praticado com liberdade de escolha de seu conteúdo, do seu destinatário, tendo em vista a conveniência e a oportunidade de sua realização. $O$ poder público faculta ao particular o uso privativo de bem público ou o desempenho de atividade material a título precário, a precariedade da autorização reside na possibilidade do poder público em revoga-la por critério de conveniência e oportunidade. A autorização, a rigor deve ser outorgada sem prazo, de tal forma que o poder público pode revogá-la, a qualquer momento, sem direito à indenização. A Tabela 4 sintetiza as diferenças entre oleodutos e gasodutos, após aprovação da Lei $\mathrm{n}^{\circ} 11.909$.

Tabela 4: Diferenças entre oleodutos e gasodutos

\begin{tabular}{lcc}
\hline & Oleodutos & Gasodutos \\
Transporte de petróleo e seus derivados & Transporte de gás natural
\end{tabular}

Fonte: Elaborado pelo autor.

\section{NOVOS DUTOS}

Conforme definido no decreto ํo 7.382, de 2/12/2010, que regulamenta a Lei $n^{\circ} 11.909$, caberá ao Ministério de Minas e Energia propor, por iniciativa própria ou por provocação de terceiros, os gasodutos de transporte que deverão ser construídos ou ampliados. Para isso, o Ministério de Minas e Energia deverá elaborar o Plano Decenal de Expansão da Malha de Transporte Dutoviário do País,

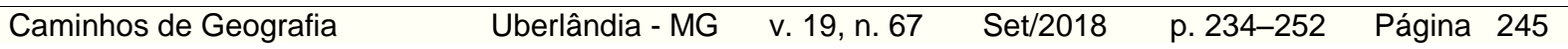


com base em estudos desenvolvidos pela Empresa de Pesquisa Energética (EPE). Os estudos a serem desenvolvidos pela EPE deverão conter, entre outros elementos, propostas de traçados, de sistemas de compressão a serem instalados e de localização de pontos de entrega, bem como as estimativas de investimento dos gasodutos. A outorga de autorização ou a licitação para a concessão da atividade dos gasodutos, será precedida de chamada pública para contratação de capacidade, ou seja, o volume diário de gás natural que o transportador é obrigado a movimentar para o carregador (agente que utilize ou pretenda utilizar o serviço de movimentação de gás natural), com o objetivo de identificar os potenciais carregadores e dimensionar a demanda efetiva. Após a definição da tarifa máxima, os carregadores ainda interessados na contratação da capacidade devem assinar um termo de compromisso junto à ANP.

Pela Lei no 9.478, novos oleodutos são propostos pelos agentes de mercado, sendo de livre iniciativa a construção e operação, não sendo necessário haver processo licitatório para a exploração destas atividades. Para implantação de novos oleodutos, conforme definido na Lei no 9.478 , não é previsto o estabelecimento de chamada pública como mecanismo de alocação da capacidade primária de transporte para oleodutos. Assim, a análise da Lei no 9.478 mostra que o arcabouço regulatório por ela definido não fornece os instrumentos necessários de redução das incertezas associadas ao mercado e de estimulo para implantação de novos oleodutos. Diferentemente dos gasodutos, que ocorre o dimensionamento prévio da demanda por capacidade e a exigência de assinatura de um termo de comprometimento pelos carregadores interessados na nova capacidade. Em última análise, a falta de instrumentos regulatórios de garantia de alocação da capacidade aos novos oleodutos gera barreira de entrada para os agentes de mercado, e afeta o desenvolvimento da rede de transporte de oleodutos como um todo.

De acordo com Porter (2004) a redução da incerteza representa um tipo de aprendizagem que afeta a estrutura da indústria, pode existir grandes incertezas quanto a assuntos como o tamanho potencial do mercado, a natureza dos compradores em potencial e de que maneira eles podem ser atingidos. Porter (2004) analisa que uma barreira de entrada pode ser criada pela necessidade de assegurar a distribuição para seu produto. Aplicando ao mercado de transporte dutoviário, considerando que a distribuição de petróleo e seus derivados já estão sendo atendidos por empresas estabelecidas, por exemplo, dos modais ferroviários e rodoviários, a empresa operadora do oleoduto precisa persuadir a aceitarem seu serviço por meio de descontos de preço, verbas para campanhas de publicidade e coisas semelhantes, o que reduz os lucros.

\section{INVESTIMENTO DE CAPITAIS}

Conforme visto na seção anterior, o custo de construção de dutos costuma ser muito elevado, com investimento em capital fixo elevado, e o prazo de retorno desses investimentos muito longo. Em relação ao orçamento de um empreendimento de dutos, Rennó e Lemgruber (2009) indicam que "[...] o custo dos tubos e do lançamento do duto representa, em média, $75 \%$ do custo total do sistema". O decreto $\mathrm{n}^{0}$ 7.382, de 2/12/2010, prevê que o Ministério de Minas e Energia poderá determinar, quando couber, a utilização do instrumento de parceria público privada, bem como a utilização de recursos provenientes da Contribuição de Intervenção no Domínio Econômico (CIDE), e da Conta de Desenvolvimento Energético (CDE), para viabilizar a construção de gasoduto de transporte proposto por sua própria iniciativa e considerado de relevante interesse público.

Nesse sentido, a utilização dos instrumentos financeiros contribui para o investimento em novos gasodutos. Para os empreendimentos de novos oleodutos, a Lei no 9.478 não prevê instrumentos financeiros de incentivo.

Porter (2004) analisa que a necessidade de investir vastos recursos financeiros de modo a competir, cria uma barreira de entrada. Embora as maiores companhias contemporâneas possuam os recursos financeiros para entrar quase em qualquer indústria, as exigências imensas de capital, como os custos de tubos e do lançamento do duto, limitam o grupo de prováveis pretendentes à entrada.

\section{LICENCIAMENTOS AMBIENTAIS}

No regime de autorização, a resolução ANP oㅡ 52, de 2/12/2015, estabelece a regulamentação de construção, a ampliação e a operação de instalações de movimentação de petróleo, seus derivados e gás natural. A resolução determina que a construção, a ampliação e a operação de instalações de movimentação de produtos regulados pela ANP, dependem de sua prévia e expressa autorização.

$\begin{array}{llllll}\text { Caminhos de Geografia } & \text { Uberlândia - MG } & \text { v. 19, n. 67 } & \text { Set/2018 } & \text { p. 234-252 } & \text { Página } 246\end{array}$


Essas autorizações serão outorgadas em 2 (duas) etapas: Autorização de Construção (AC) e Autorização de Operação (AO) (BRASIL, 2015).

O pedido de Autorização de Construção $(A C)$ será encaminhado à ANP, instruído, dentre outros documentos e informações, com cópia autenticada da Licença de Instalação (LI) expedida pelo órgão ambiental competente. O pedido de Autorização de Operação (AO) será encaminhado à ANP, contento cópia autenticada da Licença de Operação (LO) expedida pelo órgão ambiental competente.

No caso de concessão em gasodutos, o artigo 32 do decreto № 7.382, de 2/12/2010, prevê que constitui obrigação contratual do concessionário obter todas as licenças, autorizações e anuências que se fizerem necessárias para a construção e operação do gasoduto, inclusive as ambientais (BRASIL, 2010).

No Brasil, o processo de licenciamento ambiental foi devidamente disciplinado por resolução do CONAMA - Conselho Nacional do Meio Ambiente, e apresenta três etapas distintas: Licenciamento Prévio, Licenciamento de Instalação e Licenciamento de Operação. Conforme citam Rennó e Lemgruber (2009), no caso de dutos situados em mais de um Estado da Federação, o licenciamento tem de ser obrigatoriamente conduzido pelo IBAMA.

Caldas (2006) aponta que no processo de licenciamento em empreendimentos dutoviários, destacase o AIA (Avaliação do Impacto Ambiental), o EIA (Estudo de Impacto Ambiental) e o RIMA (Relatório de Impacto Ambiental). Os processos de elaboração desses documentos são de altos custos e envolvem necessidade de especialistas qualificados. Durante o processo do licenciamento ambiental, outro entrave identificado é a estruturação deficiente dos órgãos ambientais para atender à demanda gerada pelos requerimentos de licença, sobrecarregando o reduzido número de técnicos disponíveis.

De acordo com Porter (2004), os requisitos para obtenção de licença é uma forma intermediária de regulamentação governamental e tendem a restringir a entrada no mercado, fornecendo, assim uma barreira que protege as empresas existentes.

\section{CAPACITAÇÃO TÉCNICA}

No regime de concessão em gasodutos, o decreto $\mathrm{n}$ 7.382 estabelece que caberá à ANP elaborar os editais de licitação e promover o processo de licitação para a construção ou ampliação e operação dos gasodutos de transporte. No edital de licitação será indicado os requisitos exigidos dos concorrentes e os critérios de pré-qualificação, quando esse procedimento for adotado. Prevê também que a relação dos documentos exigidos e os critérios a serem seguidos para aferição da capacidade técnica, bem como para o julgamento técnico da proposta. A resolução ANP $n^{\circ} 39$, de 30/07/2014, que regula os procedimentos para realização da licitação, prevê que a ANP analisará apenas a proposta técnica da licitante vencedora da sessão pública (BRASIL, 2014b). Esta análise será realizada segundo os critérios estabelecidos no Edital, e julgada por uma Comissão Especial de Licitação (CEL), designada por Portaria pela Diretoria Colegiada da ANP.

Nos casos do regime de autorização, a resolução ANP № 52, de 2/12/2015, prevê que o pedido de Autorização de Construção (AC) deverá ser encaminhado à ANP, com memorial descritivo, assinado pelo engenheiro responsável, incluindo descrição das instalações, do serviço envolvido, do processo, das capacidades de movimentação e de armazenagem, produtos movimentados e armazenados, condições operacionais (tais como temperatura, pressão e vazão) máximas, mínimas, normais e de projeto, normas técnicas brasileiras, estrangeiras e/ou internacionais relevantes para a elaboração e execução do projeto, além de dados técnicos básicos pertinentes a cada tipo de instalação (BRASIL, 2015).

Será exigido também, atestado de conformidade do projeto da instalação, abrangendo todas as especialidades envolvidas no empreendimento, tais como engenharia civil, mecânica, elétrica, instrumentação/controle, de processo e outros necessários, expedito por entidade técnica especializada, societariamente independente da empresa solicitante da Autorização de Construção e da empresa que realizará a construção e montagem, certificando que este se encontra aderente às normas técnicas aplicáveis.

Porter (2004) explica que o declínio dos custos com a experiência parece ser o mais significativo em negócios envolvendo alto grau de participação da mão-de-obra desempenhando tarefas complicadas e/ou operações de montagem complexas. Empresas iniciantes, sem experiência, terão custos inerentemente mais altos do que as empresas estabelecidas, e têm de suportar pesados prejuízos

$\begin{array}{llllll}\text { Caminhos de Geografia } & \text { Uberlândia - MG } & \text { v. 19, n. } 67 & \text { Set/2018 } & \text { p. 234-252 } & \text { Página } 247\end{array}$


iniciais, de modo a acumular a experiência até conseguir a paridade de custos com empresas estabelecidas.

\section{ACESSO AOS DUTOS}

Está previsto na Lei no 9.478 que será facultado a qualquer o uso dos dutos de transporte ou da capacidade de movimentação de gás natural, nos termos da lei e da regulação aplicável. A ANP regulará a preferência a ser atribuída ao proprietário das instalações para movimentação de seus próprios produtos, com o objetivo de promover a máxima utilização da capacidade de transporte pelos meios disponíveis.

Nos casos de uso por terceiros interessados nos oleodutos, a resolução ANP $n^{\circ}$ 35, de 13/11/2012, prevê que o serviço de transporte de produtos será formalizado por meio de contrato firmado entre o transportador e o carregador, inclusive o carregador proprietário, e tal contrato explicitará as remunerações do serviço de transporte (BRASIL, 2012).

Para os gasodutos de transporte, o decreto no 7.382, de 2/12/2010, prevê que os carregadores iniciais terão exclusividade para exploração da capacidade contratada dos novos gasodutos de transporte (BRASIL, 2010). Caberá ao MME fixar o período de exclusividade, não podendo ser superior a dez anos e encerrar-se-á quando a movimentação em um gasoduto alcançar sua capacidade máxima de transporte contratada, ainda que o prazo fixado na chamada pública não tenha se esgotado, nos termos da regulação da ANP.

Silva (2011) explica que, com a edição da Lei do Petróleo, se consubstanciou direito de livre acesso no transporte dutoviário de petróleo e gás natural, citando o art. 58 dessa Lei que facultou a qualquer interessado o uso dos dutos de transporte existentes, ou a serem construídos, mediante remuneração adequada ao seu proprietário. Cita ainda que o objetivo desta disposição foi não só ampliar as possibilidades de fornecimento de gás natural no país, mas também fomentar a livre concorrência preceituada pela ordem econômica constitucional no setor.

Contudo, Ferraro (2010) expõe que a instituição do livre acesso permite que uma terceira parte, diferente do operador da rede, utilize a infraestrutura de dutos existente. Nesse sentido, a adoção do livre acesso modifica os direitos da empresa transportadora sobre o uso da rede de transporte. Embora os novos direitos de acesso à rede não concedam nenhum direito de propriedade e nenhum controle sobre a infraestrutura de transporte aos carregadores, eles limitam o exercício legal do direito de uso pelo operador.

Assim, embora a adoção do livre acesso seja um importante elemento para a introdução da competição no mercado de capacidade de transporte, ela gera importantes incertezas para as empresas transportadoras. Uma vez que a capacidade de transporte da malha passa a ser dividida por diferentes agentes, a empresa de transporte passa a enfrentar um problema em relação ao equilíbrio dos fluxos de gás na rede.

Novamente, mudanças na política governamental pode criar barreiras de entrada. Para Porter (2004) as influências do governo podem ter um impacto importante e real sobre a mudança estrutural da industrial, sendo mais direta a partir da regulamentação plena de variáveis básicas como a entrada na indústria, práticas competitivas ou rentabilidade.

\section{TARIFA}

Nos casos dos oleodutos as tarifas de transporte são negociadas entre as partes, a resolução ANP no 35 , de 13/11/2012, regula as remunerações praticadas pelo transportador, conforme descrito no artigo 30 as remunerações praticadas pelo transportador deverão considerar o produto e os volumes a serem transportados, as distâncias existentes entre os pontos de recepção e de entrega, carga tributária vigente, bem como custos e despesas para a prestação eficiente do serviço de transporte, incluído os custos de operação, manutenção, despesas gerais e administrativas, assim como o justo e adequado retorno sobre o capital (BRASIL, 2012).

No que se refere à regulação tarifária em gasodutos, o decreto № 7.382 estabelece que as tarifas de transporte de gás natural serão estabelecidas pela ANP, aplicando-se à tarifa máxima fixada no processo de chamada pública. Nesse sentido, a resolução ANP no 11, de 16/3/2016, prevê que no edital do processo de chamada pública disporá sobre a expectativa de tarifa de transporte máxima,

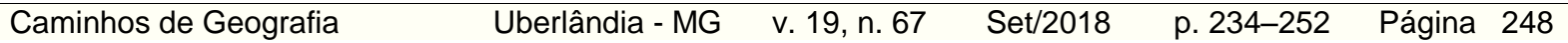


sua metodologia de cálculo e as regras que serão utilizadas no cálculo das tarifas a serem pagas pelos carregadores, bem como as regras de reajuste e revisão tarifária (BRASIL, 2016).

A resolução ANP № 15, DE 14/3/2014, estabelece critérios para cálculo das tarifas de transporte referentes aos serviços de transporte de gás natural e o procedimento para a aprovação das propostas de tarifa de transporte encaminhadas pelos transportadores para os gasodutos de transporte objeto de autorização (BRASIL, 2014a).

Pinto Junior e Silveira (1999) citam que a regulação de preços é uma das tarefas principais do regulador, pois relaciona-se diretamente com o excedente econômico e sua distribuição. As regras tarifárias são formuladas de maneira a conciliar o interesse dos consumidores e da firma regulada. Contudo, o reajustamento tarifário não é citado na resolução ANP $n^{\circ}=35$, de 13/11/2012 para oleodutos, e na resolução ANP no 15 , de 14/3/2014, não está definido critérios de reajustamento das tarifas para gasoduto. Nesse sentido, o reajustamento tarifário do segmento de gasoduto e oleoduto continua dependente da ANP.

A falta de uma definição dos princípios e da metodologia de reajuste tarifário a ser adotada pelas empresas de transporte abre espaço para adoção de comportamentos oportunistas por parte dos carregadores, uma vez que dá margem a frequentes questionamentos jurídicos do poder de mercado das empresas transportadoras.

Segundo Porter (2004) as influências do governo podem ter um impacto importante e real sobre a mudança estrutural da indústria, sendo mais direta a partir da regulamentação plena de variáveis básicas como a entrada na indústria, práticas competitivas ou rentabilidade. Alterações na regulamentação governamental de preços podem ter um impacto fundamental na estrutura da indústria, fornecendo assim uma barreira de entrada.

\section{REQUISITOS TÉCNICOS}

Nos casos dos oleodutos e gasodutos, a resolução ANP no 6 , de 03/02/2011, instituiu a gestão de segurança operacional dos dutos terrestres para movimentação de petróleo, seus derivados e gás natural. $\mathrm{Na}$ gestão de segurança operacional dos dutos terrestres são consideradas responsabilidades da empresa concessionária ou autorizada pela ANP, que o operador da instalação disponha de um sistema de gestão que atenda ao estabelecido no Regulamento Técnico de Dutos Terrestres (RTDT) para Movimentação de Petróleo, Derivados e Gás Natural, instituído pela ANP (BRASIL, 2011).

O RTDT, entre outros, estabelece as referências normativas e legais que serão aplicadas às atividades de dutos em projetos, durante construção e montagem, além de atividades relativas a operação, inspeção e manutenção de dutos e as faixas de servidão. Estabelece também requisitos mínimos que devem ser atendidos no treinamento para a qualificação do pessoal envolvido na operação, inspeção e manutenção de dutos. Além dos requisitos mínimos que devem ser atendidos para elaboração do plano de resposta a emergência e dos dutos.

Além disso, Rennó e Lemgruber (2009) indicam que os operadores de dutos deverão disponibilizar softwares que permitem a detecção e localização de vazamentos, controle de bateladas (porções) de diferentes produtos em dutos e treinamento para operadores, a fim de otimizar e proporcionar maior segurança operacional.

Para Porter (2004) existem vantagens de custos impossíveis de serem igualadas por entrantes potenciais, como tecnologia patenteada, ou seja, know-how de características de projeto são protegidos por patentes ou segredo. Outra vantagem diz respeito a curva de aprendizagem ou de experiência. Os custos declinam, pois equipamentos e processos especializados são desenvolvidos, um melhor desempenho do equipamento é alcançado, técnicas de medição e controle das operações melhoram, e assim por diante. Outro fator importante é a qualificação da mão de obra, embora as companhias maiores possam facilmente cumprir esse requisito, muitas empresas menores poderão ser bastante prejudicadas pelo aumento das despesas gerais e pela necessidade de competir por empregados mais altamente qualificados.

$\begin{array}{llllll}\text { Caminhos de Geografia } & \text { Uberlândia - MG } & \text { v. 19, n. } 67 & \text { Set/2018 } & \text { p. 234-252 } & \text { Página } 249\end{array}$




\section{CONSIDERAÇÕES FINAIS}

Pretendeu-se com este estudo buscar conhecimento quanto ao mercado do modal dutoviário aplicados ao transporte de petróleo, seus derivados e gás natural. Assim, com base no referencial bibliográfico, o modal dutoviário tem características de monopólio natural, e sua exploração comercial requer a presença ativa do Estado como regulador ou operador. Para isso, a ANP tem atribuição de regulador e fiscal da atividade de transporte. Portanto, o papel fundamental do Estado, como agente regulador, é fomentar a infraestrutura do modal dutoviário.

Este estudo teve como objetivo identificar as barreiras de entrada neste mercado. Para tanto, esta pesquisa teve um caráter qualitativo utilizando leis, decreto e resoluções da ANP como técnica para pesquisa documental. A análise dos dados foi realizada de maneira descritiva, resultando na identificação das barreiras. É importante enfatizar que as barreiras são para todas organizações, isto é, são pertinentes a questões comuns a qualquer operadora de dutos no Brasil. Além disso, conhecer e entender as barreiras que existem no setor torna o ambiente menos adverso.

A análise do conteúdo foi realizada com base na legislação e no referencial teórico apresentados, dividindo aplicação da legislação entre oleodutos e gasodutos, tendo como principal legislação a Lei no 9.478 para oleodutos e gasodutos e a lei 11.909 para gasodutos. Assim, a legislação foi agrupada nos tópicos: novos dutos, investimento de capitais, licenciamentos ambientais, capacitação técnica, acesso aos dutos, tarifas e requisitos técnicos.

Com a análise da legislação existente do modal dutoviário destinados ao transporte de petróleo, seus derivados e gás natural, foi possível verificar algumas barreiras de entrada das organizações que atuam na área:

- $\quad$ Falta de instrumentos regulatórios de garantia por demanda em novos oleodutos;

- A Lei 9.478 não prevê instrumentos financeiros de incentivos para empreendimentos de novos oleodutos;

- $\quad$ Processo de obtenção do licenciamento ambiental do empreendimento;

- Capacidade técnica atestada nas atividades de projeto, construção, ampliação, operação e manutenção de dutos de transporte;

- $\quad$ Direitos de acesso pode limitar o exercício legal do direito de uso pelo operador de dutos;

- $\quad$ Falta de uma definição dos princípios e da metodologia de reajuste tarifário dos serviços de transporte dutoviário; e

- Complexidade no plano de Manutenção, visando à operação segura das instalações, incluindo softwares com tecnologia patenteada ou protegido por segredo;

Por fim, esta pesquisa teve como propósito contribuir para o progresso das discussões sobre como estimular o crescimento do mercado dutoviário no Brasil. Entretanto, este estudo não esgota o assunto em absoluto, havendo necessidade de continuidade da discussão e do aprofundamento do tema para que a malha de dutos cresça no Brasil e se torne o modal mais seguro, viável economicamente e utilizado no transporte de petróleo, seus derivados e gás natural.

\section{REFERÊNCIAS}

AGÊNCIA NACIONAL DO PETRÓLEO. Anuário estatístico brasileiro do petróleo, gás natural e biocombustíveis: 2016. Rio de Janeiro: ANP, 2016.

ASSOCIATION OF OIL PIPE LINES. Pipelines Stretch Thousands of Miles Across the U.S. Disponível em: <http://www.aopl.org/pipeline-basics/about-pipelines/>. Acesso em: 3 set. 2016.

BIOLCHINI, Luiz C. A. Fatores críticos relativos a abertura do setor de transporte de petróleo e derivados. 2001. 98 f. Dissertação (Mestrado) - Curso de Escola Brasileira de Administração Pública, Centro de Formação Acadêmica e Pesquisa, Fundação Getúlio Vargas, Rio de Janeiro, 2001.

BOWERSOX, Donald J. et al. Gestão Logística da Cadeia de Suprimentos. Porto Alegre: AMGH, 2014. Revisão Técnica de: Alexandre Pignanelli; Tradução de: Luiz Claudio de Queiroz Faria.

$\begin{array}{llllll}\text { Caminhos de Geografia } & \text { Uberlândia - MG } & \text { v. 19, n. } 67 & \text { Set/2018 } & \text { p. 234-252 } & \text { Página } 250\end{array}$


BRASIL. Agência Nacional do Petróleo. Resolução ANP no 11, de 16 de março de 2016. Dispões sobre a oferta de serviços, cessão de capacidade contratada, troca operacional de gás natural, aprovação e registro dos contratos de serviço de transporte de gás natural - promoção dos processos de chamada pública para contratação de capacidade de transporte de gás natural e dá outras providências. Diário Oficial da União, Brasília, 18 mar. 2016.

BRASIL. Agência Nacional do Petróleo. Resolução ANP no 15, de 14 de março de 2014. Estabelece os critérios para cálculo das Tarifas de Transporte referentes aos Serviços de Transporte firme, interruptível e extraordinário de gás natural e o procedimento para a aprovação das propostas de tarifa de transporte de gás natural encaminhadas pelos transportadores para os gasodutos de transporte objeto de autorização. Diário Oficial da União, Brasília, 17 mar. 2014a.

BRASIL. Agência Nacional do Petróleo. Resolução ANP no 35, de 13 de novembro de 2012. Estabelece a regulamentação do uso por terceiros interessados, de dutos de transporte destinados à movimentação de petróleo, seus derivados e biocombustíveis, existentes ou a serem construídos. Diário Oficial da União, Brasília, 14 nov. 2012.

BRASIL. Agência Nacional do Petróleo. Resolução ANP no 39, de 30 de julho de 2014. Aprova o Regulamento, que especifica, que trata dos procedimentos para a realização de licitação para a concessão da atividade de transporte de gás natural, contemplando a construção ou ampliação e a operação de gasodutos de transporte de gás natural. Diário Oficial da União, Brasília, 31 jul. 2014b.

BRASIL. Agência Nacional do Petróleo. Resolução ANP no 52, de 2 de dezembro de 2015. Estabelece a regulamentação para a construção, a ampliação e a operação de instalações de movimentação de petróleo, seus derivados, gás natural, inclusive liquefeito (GNL), biocombustíveis e demais produtos regulados pela ANP. Diário Oficial da União, Brasília, 3 dez. 2015.

BRASIL. Agência Nacional do Petróleo. Resolução ANP no 6, de 3 de fevereiro de 2011. Aprova o Regulamento Técnico ANP oㅡ 2 de 2011 - Regulamento Técnico de Dutos Terrestres para Movimentação de Petróleo, Derivados e Gás Natural - RTDT(*), relativos aos oleodutos e gasodutos autorizados ou concedidos a operar pela ANP. Diário Oficial da União, Brasília, 7 fev. 2011.

BRASIL. Decreto no 7.382, de 2 de dezembro de 2010. Regulamenta os Capítulos I a VI e VIII da Lei no 11.909, de 4 de março de 2009, que dispõe sobre as atividades relativas ao transporte de gás natural, de que trata o art. 177 da Constituição Federal, bem como sobre as atividades de tratamento, processamento, estocagem, liquefação, regaseificação e comercialização de gás natural. Diário Oficial da União, Brasília, 3 dez. 2010.

BRASIL. Lei ํㅜ 11.909, de 4 de março de 2009. Dispõe sobre as atividades relativas ao transporte de gás natural, de que trata o art. 177 da Constituição Federal, bem como sobre as atividades de tratamento, processamento, estocagem, liquefação, regaseificação e comercialização de gás natural; altera a Lei no 9.478, de 6 de agosto de 1997; e dá outras providências. Diário Oficial da União, Brasília, 5 mar. 2009.

BRASIL. Lei no 9.478, de 6 de Agosto de 1997. Dispõe sobre a política energética nacional, as atividades relativas ao monopólio do petróleo, institui o Conselho Nacional de Política Energética e a Agência Nacional do Petróleo e dá outras providências. Diário Oficial da União, Brasília, 6 ago. 1997.

\section{CALDAS, Flaviana Venturim. Estudos de impacto ambiental em empreendimentos}

dutoviários: análise da elaboração, acompanhamento e monitoramento durante a fase de construção. 2006. 178 f. Dissertação (Mestrado) - Curso de Gestão Ambiental, Universidade Federal Fluminense, Niterói, 2006.

CECCHI, José Cesário. Interconexão e reclassificação de gasodutos: regulação, investimento, coordenação e cooperação entre união e unidades da Federação. Rio de Janeiro: Agência Nacional de Petróleo, 2012.

DI PIETRO, Maria Sylvia Zanella. Parcerias na administração pública: concessão, permissão, franquia, terceirização, parceria público-privada e outras formas. São Paulo: Atlas, 2015.

FERRARO, Marcelo Colomer. Estruturas de incentivo ao investimento em novos gasodutos: uma análise neo-institucional do novo arcabouço regulatório brasileiro. 2010. $311 \mathrm{f}$. Tese (Doutorado) - Curso de Pós-graduação em Economia da Indústria e da Tecnologia, Universidade Federal do Rio de Janeiro, Rio de Janeiro, 2010. 
FREITAS, Kátia Regina do Valle. Definição tarifária como instrumento regulatório: precificação do transporte dutoviário de gás natural no Brasil. 2004. 206 f. Dissertação (Mestrado) - Curso de Instituto de Economia, Universidade Federal do Rio de Janeiro, Rio de Janeiro, 2004.

HAGE, José Alexandre Altahyde. Bolívia, Brasil e a guerra do gás. Curitiba: Juruá, 2008.

KANDIYOTI, Rafael. Pipelines: flowing oil and crude politics. London: I. B. Tauris, 2012.

KENNEDY, John L. Oil and gas pipeline fundamentals. Tulsa, Oklahoma: Pennwell Publishing Company, 1993.

LEITE, Antonio Dias. A energia do Brasil. 3. ed. Rio de Janeiro: Lexikon, 2014.

MELO, Juliana Rabelo; FORTE, Sérgio Cavalcante; SOUSA FILHO, José Milton de. A indústria bancária brasileira: um estudo sobre as barreiras de entrada às instituições estrangeiras. Revista Ibero-americana de Estratégia, v. 13, n. 3, p. 63-76, 1 set. 2014.

https://doi.org/10.5585/riae.v13i3.2105

PEREIRA, Cesar Augusto Lorenzi; SILVA, João Antônio de Souza e; VENEZIA, Anthony Aaron. Desafios para a regulação de um mercado competitivo de gás natural no Estado de São Paulo. 2014. 81 f. Dissertação (Mestrado) - Curso de Mestrado Profissional em Gestão e Políticas Públicas, Escola de Administração de Empresas de São Paulo, Fundação Getúlio Vargas, São Paulo, 2014.

PETROBRAS: Pré-Sal. Disponível em: <http://www.petrobras.com.br/pt/nossas-atividades/areas-deatuacao/exploracao-e-producao-de-petroleo-e-gas/pre-sal/>. Acesso em: 27 mar. 2017.

PINDYCK, Robert S.; RUBINFELD, Daniel L. Microeconomia. 6. ed. São Paulo: Pearson Prentice Hall, 2006. Tradução de: Eleutério Prado, Thelma Guimarães. p.5.

PINTO JUNIOR, Helder Q.; SILVEIRA, Joyce Perin. Elementos da regulação setorial e de defesa da concorrência: uma agenda de questões para o setor de energia. Rio de Janeiro: ANP, 1999. Disponível em: <http://www.anp.gov.br/wwwanp/notas-tecnicas>. Acesso em: 15 fev. 2017.

PINTO, Marcos Barbosa. Repartição de Riscos nas Parcerias Público-Privadas. Revista do Bndes, Rio de Janeiro, v. 13, n. 25, p.155-182, jun. 2006.

PIPELINE 101. Why do we need pipelines? Disponível em: <http://www.pipeline101.org/Why-DoWe-Need-Pipelines>. Acesso em: 3 set. 2016.

PORTAL BRASIL. Setor de petróleo e gás chega a 13\% do PIB brasileiro. 2014. Disponível em: $<$ http://www.brasil.gov.br/economia-e-emprego/2014/06/setor-de-petroleo-e-gas-chega-a-13-do-pibbrasileiro>. Acesso em: 3 set. 2016.

PORTER, Michael E. Estratégia competitiva: técnicas para análise de indústrias e da concorrência. Rio de Janeiro: Elsevier, 2004. Tradução de: Elizabeth Maria de Pinho Braga.

PORTER, Michael. Vantagem competitiva: criando e sustentando um desempenho superior. Rio de Janeiro: Elsevier, 1989. Tradução de: Elizabeth Maria de Pinho Braga.

RENNÓ, Marcelo; LEMGRUBER, Nelson. O ciclo de vida de um empreendimento de dutos. In: FREIRE, José Luiz de França. Engenharia de dutos. Rio de Janeiro: ABCM, 2009. Cap. 1

SALOMÃO FILHO, Calixto. Direito concorrencial: as estruturas. São Paulo: Malheiros Editores, 1998.

SANTOS, Edmilson Moutinho dos et al. Gás natural: estratégias para uma energia nova no Brasil. São Paulo: Annablume, 2002.

SILVA, Ana Cristina da. Transporte intermodal: um estudo do modelo estadunidense-europeu vs. situação brasileira. 2003. 228 f. Dissertação (Mestrado) - Curso de Administração, Coppead, Universidade Federal do Rio de Janeiro, Rio de Janeiro, 2003.

SILVA, Ana Kátia Rodrigues. O regime de concessão para o transporte dutoviário de gás natural: o novo marco legal e as implicações para o controle externo. 2011. 35 f. Monografia (Especialização) - Curso de Especialização em Controle da Regulação, Instituto Serzedello Corrêa/TCU, Brasília, 2011.

SOUSA, Marcos Timóteo Rodrigues de. Transporte dutoviário: a circulação de combustíveis em São Paulo (1990 - 2000). Caminhos de Geografia, Uberlândia, v. 6, n. 16, p.6-13, out. 2005. 
THOMAS, José Eduardo. Fundamentos de engenharia de petróleo. Rio de Janeiro: Editora Interciência, 2001.

VASCONCELLOS, Marco Antonio Sandoval de; OLIVEIRA, Roberto Guena de; BARBIERI, Fabio. Manual de microeconomia. 3. ed. São Paulo: Editora Atlas, 2011. 183 p.

VASSALLO, Moisés Diniz. Análise de impactos econômicos setoriais e regionais decorrentes de investimentos em infraestrutura de transportes. 2015. 357 f. Tese (Doutorado) - Curso de Pósgraduação do Departamento de Economia da Faculdade de Economia, Administração e Contabilidade, Universidade de São Paulo, São Paulo, 2015.

YERGIN, Daniel. O petróleo: uma história mundial de conquistas, poder e dinheiro. São Paulo: Paz e Terra, 2012. Tradução de: Leila Marina U. Di Natale, Maria Cristina Guimarães, Maria Christina L. de Góes.

Recebido em: 10/07/2017

Aceito para publicação em: 16/10/2018 